\title{
HIV-1 and Kidney Cells: Better Understanding of Viral Interaction
}

\author{
Joanna Mikulak Pravin C. Singhal \\ Feinstein Institute for Medical Research and Long Island Jewish Medical Center, New Hyde Park, N.Y., USA
}

\section{Key Words}

HIV-associated nephropathy (HIVAN) • HIV-associated immune complex kidney disease (HIVICK) - Tubular cells • Podocytes · DEC-205

\begin{abstract}
HIV-associated nephropathy (HIVAN) is the most common disease affecting untreated seropositive patients of African descent. Besides genetic (African descent) and HIV-1 infection (environmental), specific host factors such as activation of renin-angiotensin-aldosterone system (RAAS) have also been demonstrated to play a role in the manifestation of HIVAN. The recent identification of $\mathrm{MYH9}$ as susceptible allele is a key step forward in our understanding for the pathogenesis of focal glomerulosclerosis in people of AfricanAmerican descent. HIV-1 transgenic models have significantly advanced our knowledge base in terms of role of HIV-1 genes in general and individual gene in particular in the development of renal lesions mimicking HIVAN. These studies suggest that viral replication is not needed for the development of renal lesions. Renal biopsy data from HIVAN patients suggest that renal epithelial cells express HIV-1 genes and thus it may be sufficient to invoke HIVAN phenotype in the presence of specific host and genetic factors. On the other hand, immune response to infection may be required to induce HIV-1 associated immune complex kidney disease (HIVICK). Since renal cell lack conventional HIV-1 receptors, HIV-1 entry into renal cells has been a mystery. Recently, non-
\end{abstract}

conventional pathways have been demonstrated to facilitate HIV-1 entry into renal cells in in vitro studies. These include presence of DEC-205 receptors in renal tubular cells and lipid rafts in podocytes. However, HIV-1 entry through these pathways only allows non-productive infection. It appears that the presence of specific genetic and host factors in in vivo conditions may be facilitating the development of the productive HIV-1 infection in kidney cells.

Copyright $\odot 2010$ S. Karger AG, Basel

\section{Introduction}

HIV-associated nephropathy (HIVAN) is the most common cause of renal disease in untreated HIV-1 seropositive patients and represents approximately $50 \%$ of biopsy-proven cases of HIV-1-related renal disease [1]. It is characterized by focal glomerular sclerosis (FGS) often of the collapsing variant and microcystic dilatation of tubules. HIVAN occurs predominantly in patients of African descent and is considered to be caused by a combination of genetic, environmental and host factors [2]. HIV-1 infection is also associated with other immune-mediated renal diseases and is known as HIV immune complex kidney disease (HIVICK). Manifestation of HIVAN phenotype requires presence of multiple factors including genetic, environmental and host factors; therefore, to have insight into the HIVAN pathogenesis, one has to understand the involved basic science concepts. The present re-

\section{KARGER}

(c) 2010 S. Karger AG, Basel

Fax +41613061234

E-Mail karger@karger.ch

www.karger.com
Accessible online at:

www.karger.com/nee
Pravin C. Singhal, MD

100 Community Drive

Great Neck, NY 11021 (USA)

Tel. +1 516465 3010, Fax +1 5164653011

E-Mail singhal@lij.edu 


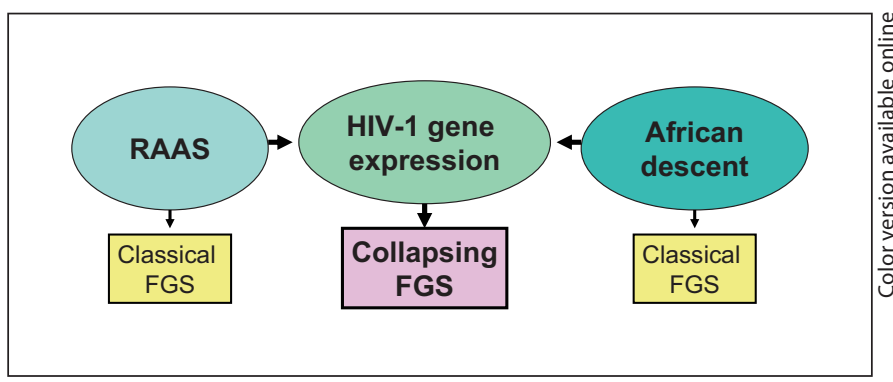

Fig. 1. Confluence of factors contributing to the pathogenesis of HIVAN.

view has been designed to simplify the understanding of basic science concepts associated with the pathogenesis of HIVAN. Moreover, data pertaining to HIV-1 entry into renal cell has been reported only in in vitro studies and that too in cell culture system; therefore, at present we have only limited knowledge pertaining to in vivo HIV-1 entry into kidney cells.

\section{Genetic Factors Contributing to the Pathogenesis of HIVAN}

The recent reports have identified MYH9, a nonmuscle myosin, as an associated gene for the development of idiopathic and HIV-1-related focal segmental glomerulosclerosis in people of African descent [3]. In one of the studies, Papeta et al. [4] used combination of a gene profiling and linkage analysis to identify three genomic loci that regulate a network of podocyte genes and found that two of these loci confer disease susceptibility in a transgenic model of HIVAN. In another study, Kopp et al. [3] found the E-1 haplotype of MYH9 had a large frequency difference between African-Americans (60\%) versus European-Americans (4\%) and was strongly associated with renal disease. MYH9 is highly expressed in podocytes; however, the mechanism by which this non-coding polymorphism enhances disease susceptibility is not clear.

\section{Environmental Factors Contributing to the Pathogenesis of HIVAN}

There is enough evidence that indicate that kidney cells are infected in patients with HIVAN $[1,5]$. The presence of HIV-1 mRNA has been detected in epithelia in renal biopsy studies [1]. That highly active antiretroviral therapy (HAART) has been shown to slow down the progression of renal failure in HIVAN patients suggests direct viral effects on the kidney in HIVAN pathogenesis [6]. Moreover, relapse of HIVAN has been reported after cessation of HAART [7].

\section{Host Factors Contributing to the Pathogenesis of HIVAN}

Activation of the renin-angiotensin-aldosterone system (RAAS) in general, and Ang II in particular, have been implicated in the development of HIVAN [8-10]. Blockade of the production of Ang II as well as blocking the effect of Ang II has been demonstrated to slow down the progression of HIVAN in humans as well as in experimental animal models of the HIVAN [8-10]. Along the same lines, infusion of Ang II in HIVAN mice has been demonstrated to accelerate the development of renal lesions [11]. Since the presence of host factors such as activation of the RAAS and or African descent in other disease models are associated with classical FGS only (but not the collapsing variant), it appears that renal cell HIV1 gene expression is a prerequisite for the development of HIVAN. As proposed in figure 1, HIVAN pathogenesis requires a confluence of host (RAAS activation), genetic (African descent) and environmental (HIV-1 gene expression) factors to develop the overt HIVAN phenotype.

\section{Route of HIV-1 Entry into Renal Cells Is Controversial}

HIV-1 enters susceptible cells by fusion of its envelope with the plasma membrane after binding to the CD4 molecule and interaction with the chemokine coreceptors CCR5 or CXCR4. However, HIV-1 entry into CD4-negative human cells has also been widely reported [12]. In the majority of instances, the HIV-1 entry into CD4-negative cells occurred through the endocytic pathways.

In the past, expression of HIV-1 receptors by renal cell has been a controversial issue [1]. However, the present consensus indicates that renal cells do not express classical HIV-1 receptors such as CD4, CXCR4, and CCR5 [1, 13]. Since renal cells do not express conventional HIV-1 receptors but have been shown to harbor HIV-1, the role of nonconventional receptors was suspected by many investigators [1]. The role of C-type lectins in HIV-1 pathogenesis has been highlighted by studies demonstrating 
their capability to bind HIV-1 in a CD4-independent manner [14]. This large group of proteins such as dendritic cell-specific ICAM-3-grabbing nonintegrin (DCSIGN), macrophages mannose receptor (MMR), and DEC-205 are specialized in the recognition of carbohydrate structures present on cellular and viral proteins and are implicated in several processes, including cell adhesion and antigen presentation. DC-SIGN is highly expressed in dendritic cells and was originally cloned for its ability to bind and internalize heavily glycosylated HIV-1 glycoprotein (gp) 120 protein [14]. DEC-205 is an endocytic receptor that plays an important role in antigen presentation [14]. Recently, DEC-205 has been demonstrated to serve as a receptor for HIV-1 entry into tubular cells [15].

Lipid rafts are membrane microdomains enriched with cholesterol and glycosphingolipids (GSLs). Many viruses including HIV-1 utilize a lipid raft-mediated endocytosis for their entry [16]. HIV-1 entry into T cells takes place through lipid rafts by using the raft-colocalized CD4 and chemokine receptors. Depletion of cholesterol from the target cell membrane has been associated with significant inhibition of productive infection in $\mathrm{T}$ cells. Recently, HIV-1 has been reported to utilize lipid rafts for its entry into human podocytes [17].

\section{Role of HIV-1 Transgenic Models in the Understanding of HIVAN}

In the beginning of the HIV era, there was no ideal model of HIVAN [1]. Rodents cannot be infected with HIV-1, and transgenic techniques allow only for the study of the post-integration phase of the HIV-1 cycle. Moreover, all HIV-1 transgenics use replication defective proviral DNA, eliminating the possibility of the formation of a new virus. Therefore, these transgenics are unlikely to have immune response typical of viral infection. Nevertheless, viral proteins often hijack the host cellular machinery to support viral replication, altering normal cellular function and thus mimicking the clinical manifestation of AIDS. However, many HIV-Tg mice that express HIV-1 genes in renal epithelial cells do not develop renal disease [18]. Moreover, specific host/genetic factors are needed for the development of the full HIVAN phenotype. These findings further confirm that expression of viral genes alone (not replicative infection) in the presence of specific genetic and host factors can induce HIVAN. On the other hand, viral replication or immune response to infection may be required to induce HIVICK. Although at present these hypotheses are still debated, this is the prevailing view for the wide spectrum of renal lesions in patients with HIV-1 infection.

\section{Tubular Cells Serve as a Reservoir for HIV-1}

Infection of renal tubular cells both in in vivo and in vitro studies has been reported [5]. Tubular epithelial cells collected from children with HIVAN have been demonstrated to undergo HIV-1 infection in in vitro studies [5]. Interestingly, in an isolated case report, Winston et al. [19], demonstrated that HIV-1 gene expression by renal tubular cells persisted despite there was no viral load in the circulating blood. This group of investigators suggested that renal tubular cells have potential to serve as a reservoir for HIV-1 infection.

\section{HIV-1 Enters into Tubular Cells via DEC-205 Receptor}

Both human proximal tubular cell line (HK2 cells) and primary renal tubular cells have been recently demonstrated to express DEC-205 receptors [15]. Renal tubular cells also expressed DEC-205 in vivo [15]. In in vitro studies, interaction of HIV-1 with DEC-205 results in the internalization of the virus and the establishment of a nonproductive persistent infection of HK2 cells. The virus can be rescued by cocultivation of HIV-1-harboring HK2 cells with primary macrophages as well as T cells [15]. HIV-1 infection is blocked by pretreatment with specific anti-DEC-205 antibody. Moreover, expression of DEC-205 in 293T cells lacking the DEC-205 receptor renders them susceptible to HIV-1 infection. These findings suggest that DEC-205 acts as an HIV-1 binding receptor mediating internalization of the virus into cells expressing DEC-205, thereby allowing them to serve as a viral reservoir from which the virus can be rescued and disseminated through encounters with immune cells. These findings were further confirmed in primary renal tubular cells [15].

\section{Proposed Role of GSLs in Tubular Cell HIV-1 Entry}

Recently Khan et al. [20] demonstrated presence of globotriaosyl ceramide $\left(\mathrm{Gb}_{3}\right.$, it is the functional receptor for Shiga or Vero toxin on the cell surface) in both glomerular and tubular cell. Interestingly, HIV-1gp120 
Table 1. Role of HIV-1 genes in the induction of kidney cell injury

\begin{tabular}{|c|c|}
\hline $\begin{array}{l}\text { HIV-1 } \\
\text { genes }\end{array}$ & Findings indicating the role in kidney cell injury \\
\hline$v p r$ & $\begin{array}{l}\text { Mice transgenic for Vpr alone develop FGS [24]. Vpr } \\
\text { expression in podocyte alone has been demonstrated } \\
\text { to cause FGS [24]. }\end{array}$ \\
\hline nef & $\begin{array}{l}\text { Podocyte expression of nef alone can cause podocyte } \\
\text { proliferation and dedifferentiation [25]. } \\
\text { Its expression with other HIV-1 genes in podocytes } \\
\text { alone can cause FGS [24]. Podocyte expression of nef } \\
\text { alone is also associated with mesangial cell prolifera- } \\
\text { tion [35]. }\end{array}$ \\
\hline env & $\begin{array}{l}\text { gp160 and g120 modulate proliferation and apopto- } \\
\text { sis in mesangial cells }[24,32,33]\end{array}$ \\
\hline tat & $\begin{array}{l}\text { Mice transgenic for tat and vpr genes develop FGS } \\
\text { [24]. Podocyte expression of tat along with other } \\
\text { HIV-1 genes can cause FGS [14]. }\end{array}$ \\
\hline rev & $\begin{array}{l}\text { Its expression in podocytes alone along with other } \\
\text { HIV-1 genes can result in FGS [24]. }\end{array}$ \\
\hline vif & $\begin{array}{l}\text { Its expression in podocytes alone along with other } \\
\text { HIV-1 genes can result in FGS [24]. }\end{array}$ \\
\hline $\begin{array}{l}\text { gag, pol, } \\
\text { and } v p u\end{array}$ & No reported role in kidney cell injury [24]. \\
\hline
\end{tabular}

could bind to $\mathrm{Gb}_{3}$ in tubular cells only (VT-1-dependent and detergent-sensitive manner). Since the binding of VT-1 to $\mathrm{Gb}_{3}$ in renal cells contributed to the pathogenesis of renal lesions in hemolytic uremic syndrome in children, these investigators speculated that interaction between gp120 and $\mathrm{Gb}_{3}$ might be playing a role in the entry of HIV-1 into tubular cells. However, this hypothesis needs to be tested.

\section{HIV-1 Induces Apoptosis in Tubular Cells}

Renal tubular cells infected with HIV-1 as well as transduced with HIV-1 transgene (NL4-3, an HIV construct carrying all HIV-1 genes except gag and pol) have been reported to undergo apoptosis [21]. Moreover, HIV1 proteins such as HIV-1 envelope gp120 (it constitutes the envelope surface unit of the HIV-1 virus) [22] have been reported directly to induce apoptosis of human tubular by activation of TGF (transforming growth factor)$\beta$ and smads (small/mothers against decapentaplegic ho- mologues, downstream signaling genes of TGF- $\beta$ ) [22]. Additionally, human tubular cells expressing either Vpr or gp120 proteins have been demonstrated to undergo apoptosis [21, 23]. Human tubular cells expressing the HIV-1 transgene have also been demonstrated to undergo cell cycle arrest in G2/M phase [21]. Although it appears that at present we have limited knowledge of tubular cell entry of HIV-1, there is plenty of data indicating the direct effect of HIV-1 on tubular cells in general and HIV-1 proteins in particular contributing to the pathogenesis of HIVAN.

\section{HIV-1 and Endothelial Cells}

Although presence of endoplasmic reticular bodies in endothelial cells is a frequently encountered finding in patients of HIVAN, the role of endothelial cell HIV-1 infection in the pathogenesis is poorly understood. Cultured primary human glomerular endothelial cells express CXCR4, and cells can fuse with HIV-1 gp120 by a CD4 independent mechanism [24]. However, to have a clear understanding of the pathogenesis of HIVAN, it will be important to delineate the involved mechanism of HIV-1 passage across endothelial cells to reach podocytes and tubular cells.

\section{Role of Podocytes in HIVAN}

Podocytes are considered to be the key cell contributing to the HIVAN phenotype [1]. Renal biopsy data from HIVAN patients indicate that podocytes are infected with HIV-1 [1]. Moreover, in situ hybridization as well as polymerase chain reaction indicated that podocytes contained viral RNA and proviral DNA in HIVAN patients [25]. In HIVAN, podocyte dysfunction appears to be the result of the combination of the direct effect of viral gene products expression, host, and genetic factors [26-28] (table 1).

\section{Problems Encountered in Carrying in vitro Studies in Podocytes}

The study of podocytes in culture had been controversial because of its terminally differentiated phenotype. However, this problem was taken care of by the development of a conditionally immortalized human podocyte cell line by transfection with the temperature-sensitive 
SV40-T gene [28]. These cells provide an accurate phenotype for studying proteins and pathways involved in human renal disorders including HIVAN.

\section{HIV-1 Entry into Podocytes}

A single study demonstrated the presence of CXCR4 in human podocytes [30]. However, the presence of conventional HIV-1 receptors in podocytes remains controversial [13]. Recently, HIV-1 entry into human podocytes has been reported in in vitro studies [17]. In these studies, podocyte viral entry was inhibited by disruption of lipid rafts [17]. On the other hand, cholesterol repletion to cholesterol depleted cells normalized the viral entry into podocytes [17]. These findings are consistent with the reported observations on dendritic cells (DCs)-HIV-1 binding and uptakes in immature DCs occur through a cholesterol-dependent pathway [31].

\section{HIV-1 Induces Podocyte Apoptosis through the Induction of Oxidative Stress}

Podocytes expressing HIV-1 have been demonstrated to display enhanced levels of oxidative stress [32]. In HIV1-infected podocytes, HIV-1 activated the p66ShcA pathway, which was associated with deactivation of FOXO3Amediated stress response program [32]. Consequently, HIV-1 transduced podocytes showed enhanced DNA damage and a compromised DNA repair program [32]. These effects of HIV-1 promoted apoptosis in human podocytes. On the other hand, podocytes lacking either p66ShcA or FOXO3A were resistant to the oxidative as well as pro-apoptotic effect of HIV-1 [28]. Interestingly, the HIV-1 protein Tat has been reported to stimulate proliferation of human podocytes in in vitro studies [33]; whereas, the HIV-1 protein Nef stimulated proliferation of mouse podocytes [34] but not of human podocytes [unpubl. obs.]. These in vitro findings are consistent with some of the characteristic in vivo podocyte phenotypes in HIVAN patients [1].

\section{HIV-1 Proteins Have a Bimodal Growth Effect on Mesangial Cells}

Human mesangial cells do not express conventional HIV-1 receptors. However, occurrence of HIV-1 infection in mesangial cells through orphan $\mathrm{G}$ protein coupled re- ceptors has been reported in in vitro studies [35]. Moreover, both gp160 and gp120 have been demonstrated to have a bimodal effect on mesangial cell growth [36]. At lower concentrations, these HIV-1 proteins stimulated mesangial cell proliferation, whereas at higher concentrations these HIV-1 proteins induced mesangial cell apoptosis. Gp120-induced mesangial cell proliferation was mediated through the activation of the Akt pathway [37]. Interestingly, mesangial cells harvested from HIV-1 transgenic mice showed both accelerated rate of proliferation as well as of apoptosis [38]. Since antioxidants were able to inhibit these growth characteristics of mesangial cells, these pro-mitogenic and pro-apoptotic effects of the HIV-1 transgene were attributed to the levels of ongoing oxidative stress [38].

\section{Role of ApoE in HIV-1-Induced Mesangial Cell Proliferation}

Recently, podocyte HIV-1 expression has been reported to attenuate podocyte apoE expression in both in vitro and in vivo studies [39]. ApoE stimulates production of perlecan (proteoglycan) by podocytes [40]. In vivo mesangial cells are quiescent because of the sustained production of perlecan (an inhibitor of mesangial cell proliferation). However, if the production of perlecan decreases as a result of podocyte injury, it would promote mesangial cell proliferation. On that account, apoE null mice have been demonstrated to develop mesangial cell proliferation followed by glomerulosclerosis [40]. Since podocyte HIV-1 infection also attenuated podocyte expression of apoE, it appeared that mesangial cell proliferation seen in HIVAN might have occurred in the absence of mesangial cell HIV-1 infection. Interestingly, mesangial expansion has been considered a precursor of conventional focal glomerulosclerosis; therefore, patients with HIV-1 infection manifesting in the form classical focal glomerulosclerosis would also be considered as a variant of HIVAN.

\section{Conclusions}

HIVAN is the manifestation of viral infection, genetic predisposition and the presence of specific host factors (fig. 1). Clinical data not only suggest the role of direct viral infection but kidney cells also seem to serve as a reservoir for HIV-1. However, renal cells do not express conventional HIV-1 receptors. In vitro data suggest that HIV- 
1 can enter into kidney cells through nonconventional receptors and has the potential to transmit the virus to the target cells. Thus, both in vitro and in vivo data indicate the role of kidney cells as a reservoir; however, the involved mechanism for the development of kidney cell HIV-1 infection (productive) is not clear.

\section{Acknowledgement}

This work was supported from RO1 grants DK083931 and DK084910 from the National Institutes of Health, Bethesda, Md., USA.

\section{References}

1 Marras D, Bruggeman LA, Gao F, Tanji N, Mansukhani MM, Cara A, Ross MD, Gusella GL, Benson G, D’Agati VD, Hahn BH, Klotman ME, Klotman PE: Replication and compartmentalization of HIV-1 in kidney epithelium of patients with HIV-associated nephropathy. Nat Med 2002;8:522-526.

$\checkmark 2$ Kimmel PL, Barisoni L, Kopp JB: Pathogenesis and treatment of HIV-associated renal diseases: lessons from clinical and animal studies, molecular pathologic correlations, and genetic investigations. Ann Intern Med 2003;139:214-226.

-3 Kopp JB, Smith MW, Nelson GW, Johnson RC, Freedman BI, Bowden DW, Oleksyk T, McKenzie LM, Kajiyama H, Ahuja TS, Berns JS, Briggs W, Cho ME, Dart RA, Kimmel PL, Korbet SM, Michel DM, Mokrzycki MH, Schelling JR, Simon E, Trachtman H, Vlahov $\mathrm{D}$, Winkler CA: MYH9 is a major-effect risk gene for focal segmental glomerulosclerosis. Nat Genet 2008;40:1175-1184

-4 Papeta N, Chan KT, Prakash S, Martino J, Kiryluk K, Ballard D, Bruggeman LA, Frankel R, Zheng Z, Klotman PE, Zhao H, D'Agati VD, Lifton RP, Gharavi AG: Susceptibility loci for murine HIV-associated nephropathy encode trans-regulators of podocyte gene expression. J Clin Invest. 2009;119:11781188.

5 Ray PE, Liu XH, Henry D, Dye L 3rd, Xu L, Orenstein JM, Schuztbank TE: Infection of human primary renal epithelial cells with HIV-1 from children with HIV-associated nephropathy. Kidney Int 1998;53:12171229.

-6 Atta MG, Gallant JE, Rahman MH, Nagajothi N, Racusen LC, Scheel PJ, Fine DM: Antiretroviral therapy in the treatment of HIVassociated nephropathy. Nephrol Dial Transplant 2006;21:2809-2813.

-7 Scialla JJ, Atta MG, Fine DM: Relapse of HIV-associated nephropathy after discontinuing highly active antiretroviral therapy. AIDS 2007;21:263-264.

8 Burns GC, Paul SK, Toth IR, Sivak SL: Effect of angiotensin-converting enzyme inhibition in HIV-associated nephropathy. J Am Soc Nephrol 1997;8:1140-1146.

-9 Bird JE, Durham SK, Giancarli, Gitliz PH, Pandya DG, Dambach DM, Mozes MM, Kopp JB: Captopril prevents nephropathy in HIV-transgenic mice. J Am Soc Nephrol 1998;9:1441-1447.
10 Hiramatsu N, Hiromura K, Shigehara T, Kuroiwa $\mathrm{T}$, Ideura $\mathrm{H}$, Sakurai $\mathrm{N}$, Takeuchi $\mathrm{S}$, Tomioka M, Ikeuchi H, Kaneko Y, Ueki K, Kopp JB, Nojima Y: Angiotensin II type 1 receptor blockade inhibits the development and progression of HIV-associated nephropathy in a mouse model. J Am Soc Nephrol 2007;18:515-527.

11 Ideura H, Hiromura K, Hiramatsu N, Shigehara T, Takeuchi S, Tomioka M, Sakairi T, Yamashita S, Maeshima A, Kaneko Y, Kuroiwa T, Kopp JB, Nojima Y: Angiotensin II provokes podocyte injury in murine model of HIV-associated nephropathy. Am J Physiol Renal Physiol 2007;293:F1214-F1221.

12 Haraouse JM, Kunsch C, Hartle HT, Laughlin MA, Hoxie JA, Wigdahl B, GonzalezScarano F: CD4-independent infection of human neural cells by immunodeficiency virus type 1. J Virol 1989;63:2527-2533.

13 Eitner F, Cui Y, Hudkins KL, Stokes MB, Segerer S, Mack M, Lewis PL, Abraham AA, Schlondorff D, Gallo G, Kimmel PL, Alpers CE: Chemokine receptor CCR5 and CXCR4 expression in HIV-associated kidney disease. J Am Soc Nephrol 2000; 11:856-867.

14 Curtis BM, Scharnowske S, Watson AJ: Sequence and expression of a membrane-associated C-type lectin that exhibits CD4-independent binding of human immunodeficiency virus envelope glycoprotein gp120. Proc Natl Acad Sci USA 1992;89: 8356-8360.

15 Hatsukari I, Singh P, Hitosugi N, Messmer D, Valderrama E, Teichberg S, Chaung W, Gross E, Schmidtmayerova H, Singhal PC: DEC-205-Mediated internalization of HIV1 results in the establishment of silent infection in renal tubular cells. J Am Soc Nephrol 2007;18:780-787.

16 Mañes S, del Real G, Lacalle RA, Lucas P, Gómez-Moutón C, Sánchez-Palomino S, Delgado L, Alkamí J, Mira E, Martínez A-C: Membrane raft microdomains mediate lateral assemblies required for HIV-1 infection. EMBO Rep 2000;1:190-196.

17 Mikulak J and Singhal PC: HIV-1 entry is mediated through lipid rafts in human podocytes. Kidney Int, in press.

18 Zhong J, Zuo Y, Ma J., et al: Expression of HIV-1 genes in podocytes alone can lead to the full spectrum of HIV-1-associated nephropathy. Kidney Int 2005;68:1048-1060.
19 Winston JA, Bruggeman LA, Ross MD, Jacobson J, Ross L, D’Agati VD, Klotman PE, Klotman ME: Nephropathy and establishment of a renal reservoir of HIV type 1 during primary infection. N Engl J Med. 2001; 344:1979-1984

20 Khan F, Proulx F, Lingwood CA: Detergentresistant globotriaosyl ceramide may define verotoxin/glomeruli-restricted hemolytic uremic pathology. Kidney Int 2009;75: 1209-1216.

21 Rosenstiel PE, Gruosso T, Letourneau AM, Chan JJ, LeBlanc A, Husain M, Najfeld V, Planelles V, D’Agati VD, Klotman ME, Klotman PE: HIV-1 Vpr inhibits cytokinesis in human proximal tubule cells. Kidney Int 2008;74:1049-1058.

22 Kapasi AA, Fan S, Singhal PC: p300 modulates HIV-1 gp120-induced apoptosis in human proximal tubular cells: associated with alteration of TGF-beta and Smad signaling. Nephron Exp Nephrol 2006;102:e30-e38.

23 Vashistha H, Husain M, Kumar D, Singhal PC: Tubular cell HIV-1 gp120 expression induces caspase 8 activation and apoptosis. Ren Fail 2009;31:303-312.

24 Ray PE, Soler Garcia AA, Xu L, et al: Fusion of HIV-1 envelope-expressing cells to human glomerular endothelial cell through CXCR4-mediated mechanism. Pediatr Nephrol 2005;20:1401-1409.

25 Tanji N, Ross MD, Tanji K, Bruggeman LA, Markowitz GS, Klotman PE, D'Agati VD: Detection and localization of HIV-1 DNA in renal tissues by in situ polymerase chain reaction. Histol Histopathol 2008;21:393-401.

26 Husain M, D’Agati VD, He JC, Klotman ME, Klotman PE: HIV-1 Nef induces dedifferentiation of podocytes in vivo: a characteristic feature of HIVAN. AIDS 2005;19:1975-1980.

27 Zuo Y, Matsusaka T, Zhong Jet al: HIV-1 genes vpr and nef synergistically damage podocytes, leading to glomerulosclerosis. J Am Soc Nephrol 2006; 17:2832-2843.

28 Kajiyama W, Kopp JB, Marinos NJ, Klotman PE, Dickie P: Glomerulosclerosis and viral gene expression in HIV-transgenic mice: role of nef. Kidney Int 2000;58:1148-1159.

29 Saleem MA, O'Hare MJ, Reiser J, Coward RJ, Inward CD, Farren T, Xing CY, Ni L, Mathieson PW, Mundel P: A conditionally immortalized human podocyte cell line demonstrating nephrin and podocin expression. J Am Soc Nephrol 2002;13:630-638. 
>30 Huber TB, Reinhardt HC, Exner M, Burger JA, Kerjaschki D, Saleem MA, Pavenstädt H: Expression of functional CCR and CXCR chemokine receptors in podocytes. J Immunol 2002; 168:6244-6252.

-31 Gummuluru S, Rogel M, Stamatatos L, Emerman M: Binding of human immunodeficiency virus type 1 to immature dendritic cells can occur independently of DC-SIGN and mannose binding C-type lectin receptors via a cholesterol-dependent pathway. J Virol 2003;77:12865-12874.

>32 Husain M, Meggs LG, Vashistha H, Simoes S, Griffiths KO, Kumar D, Mikulak J, Mathieson PW, Saleem MA, Del Valle L, PinaOviedo S, Wang JY, Seshan SV, Malhotra A, Reiss K, Singhal PC. Husain M, Meggs LG, Vashistha H, Simoes S, Griffiths KO, Kumar D, Mikulak J, Mathieson PW, Saleem MA, Del Valle L, Pina-Oviedo S, Wang JY, Seshan SV, Malhotra A, Reiss K, Singhal PC: Inhibition of P66SHCA longevity gene rescues podocytes from HIV-1-induced oxidative stress and apoptosis. J Biol Chem. 2009;284: 16648-16658.
33 Conaldi PG, Bottelli A, Baj A, Serra C, Fiore L, Federico G, Bussolati B, Camussi G: Human immunodeficiency virus-1 tat induces hyperproliferation and dysregulation of renal glomerular epithelial cells. Am J Pathol 2002;161:53-61.

34 Husain M, Gusella GL, Klotman ME, Gelman IH, Ross MD, Schwartz EJ, Cara A, Klotman PE: HIV-1 Nef induces proliferation and anchorage-independent growth in podocytes. J Am Soc Nephrol 2002;13:18061815.

35 Tokizawa S, Shimizu N, Hui-Yu L, Deyu F, Haraguchi Y, Oite T, Hoshino H: Infection of mesangial cells with HIV and SIV: identification of GPR1 as a coreceptor. Kidney Int 2000;58:607-617.

36 Singhal PC, Sharma P, Reddy K, Sanwal V, Rawal J, Gibbons N, Franki N: HIV-1 gp160 envelope protein modulates proliferation and apoptosis in mesangial cells. Nephron 1997;76:284-295.

37 Kapasi AA, Fan S, Singhal PC: Role of 14-33epsilon, c-Myc/Max, and Akt phosphorylation in HIV-1 gp 120-induced mesangial cell proliferation. Am J Physiol Renal Physiol 2001;280:F333-F342.
38 Mongia A, Bhaskaran M, Reddy K, Manjappa N, Baqi N, Singhal PC: Protease inhibitors modulate apoptosis in mesangial cells derived from a mouse model of HIVAN. Kidney Int 2004;65:860-870.

-39 Arora S, Husain M, Kumar D, Patni H, Pathak S, Mehrotra D, Reddy VK, Reddy LR, Salhan D, Yadav A, Mathieson PW, Saleem MA, Chander PN, Singhal PC. Arora S, Husain M, Kumar D, Patni H, Pathak S, Mehrotra D, Reddy VK, Reddy LR, Salhan D, Yadav A, Mathieson PW, Saleem MA, Chander PN, Singhal PC: Human immunodeficiency virus down regulates podocyte apoE expression. Am J Physiol Renal Physiol 2009; 297:F653-F661.

40 Chen G, Paka L, Kako Y, Singhal P, Duan W, Pillarisetti SA: Protective role for kidney apolipoprotein E: regulation of mesangial cell proliferation and matrix expansion. J Biol Chem 2001;276:49142-49147. 